\title{
CHEMICAL MODIFICATION STUDIES ON PROTEIN SYNTHESIS INHIBITOR II FROM BARLEY SEEDS. IDENTIFICATION OF AN ESSENTIAL TYROSYL RESIDUE
}

\author{
by \\ KATSUHIKO ASANO ${ }^{13}$ and BIRTE SVENSSON ${ }^{2)}$ \\ Department of Chemistry, Carlsberg Laboratory, \\ Gamle Carlsberg Vej 10, DK-2500 Copenhagen Valby \\ 1) Present address: Applied Bioscience Laboratory, Kirin Brewery Co., Ltd., \\ 2-2, Soujamachi 1chome, Maebashi-shi, 371 Japan \\ 2) To whom correspondence should be addressed
}

Keywords: Nitration, reverse-phase HPLC, 1,2-cyclohexanedione, carbamylation, carbodiimide, diethylpyrocarbonate, N-bromosuccinimide, dimethyl(2-methoxy5-nitrobenzyl)sulfonium bromide, hydrogen peroxide, cell-free protein synthesis

An inhibitor of animal cell-free protein synthesis from barley seeds (inhibitor II) has been chemically modified by means of group-specific reagents. Specific nitration of a single tyrosyl residue caused a substantial loss of the inhibitory activity. After cyanogen bromide cleavage and subfragmentation of the nitrated fragment by endoproteinase Lys-C, the essential residue was identified as $\operatorname{Tyr}(86)$ in the primary structure. Chemical modifications of carboxyl groups, lysyl residues, and arginyl residues also led to reduction of the activity, whereas modifications of tryptophanyl or methionyl residues had no significant effects.

\section{INTRODUCTION}

The translation inhibitor from barley seeds catalytically inhibits the animal cell-free protein synthesis $(1,17)$. The inhibitor was recently found to, reduce the activity of the GTPase that depends upon elongation factor 1 and ribosomes (17). The mechanism of inhibition has not been elucidated in detail, but it seems to differ from mechanisms suggested for related translation inhibitors such as ricin A-chain (2, $10,25)$, pokeweed antiviral protein $(\mathrm{PAP})(2,10)$ and $\alpha$-sarcin from the mold Aspergillus giganteus $(9,21)$.

The barley inhibitor belongs to the class of single chain translation inhibitors from higher plants (4). As the first from this protein family its complete amino acid sequence (3) was recently described. It shows a distant sequence homology with the ricin A-chain plus possibly other plant translation inhibitors for which only $\mathrm{NH}_{2}$-terminal sequences are reported (3). Arginyl and tyrosyl residues were previously indicated to be

\footnotetext{
Abbreviations: $\mathrm{CHD}=1,2$-cyclohexanedione; $\mathrm{DEP}=$ diethylpyrocarbonate; $\mathrm{DMNBS}-\mathrm{Br}=\operatorname{dimethyl}(2-\mathrm{methoxy}-5$ nitrobenzyl)sulfonium bromide; EDC = 1-ethyl-3-(3-dimethylaminopropyl)carbodiimide; EDTA = ethylenediamine tetraacetic acid, disodium salt; $\mathrm{ID}_{50}=$ concentration of inhibitor causing $50 \%$ inhibition of in vitro translation; NBS = N-bromosuccinimide; PAP = pokeweed antiviral protein; RP-HPLC $=$ reverse-phase high performance liquid chromatography; TNM = tetranitromethane; Tris = 2-amino-2-hydroxymethylpropane-1,3-diol.
} 
involved in the function of PAP (14), the ricin A-chain $(27,28)$, and gelonin (26), but in no case was the position of the essential residues determined in the primary structures. In the present study a specific tyrosyl residue required for activity is identified in the sequence of barley translation inhibitor II. Furthermore, chemical modifications are used to elucidate other residues involved in the function of the inhibitor.

\section{MATERIALS AND METHODS}

\subsection{Materials}

Barley seed translation inhibitor II (1) and barley hordein mRNA $(5,12)$ were prepared as previously described.

The sources of chemicals were as follows: mRNA-dependent rabbit reticulocyte lysate from Amersham International, Amersham, U.K.; L- $\left[{ }^{35} \mathrm{~S}\right]$ methionine from New England Nuclear Chemicals, Dreieich, F.R.G.; dimethyl (2-methoxy-5-nitrobenzyl)sulfonium bromide (DMNBS-Br), N-bromosuccinimide (NBS) and tetranitromethane (TNM) from Fluka AG, Buchs, Switzerland; potassium cyanate and hydrogen peroxide from E. Merck, Darmstadt, F.R.G.; 1-ethyl-3-(3-dimethylaminopropyl)carbodiimide (EDC), glycine ethyl ester- $\mathrm{HCl}$, diethylpyrocarbonate (DEP) and cyanogen bromide from Sigma Chemical Co., St. Louis, MO; 1,2-cyclohexanedione (CHD) from Pierce Chemical Co., Rockford, IL; endoproteinase Lys-C from Boehringer Mannheim, Mannheim, F.R.G. All other chemicals were of analytical grade.

\subsection{Chemical modifications}

Translation inhibitor $\left(450 \mu \mathrm{g} \cdot \mathrm{ml}^{-1}\right.$, in 50 mM-Tris- $\mathrm{HCl}, \mathrm{pH} 8.0$ ) was nitrated by two portions of TNM ( $1 \%$ in $95 \%$ ethanol), added with an interval of $1 \mathrm{~h}$ to a final concentration of $0.25 \mathrm{~mm}$. This mixture was then left for $1 \mathrm{~h}$ at room temperature with stirring and the reaction was subsequently stopped by dialysis against $50 \mathrm{~mm}$-Tris- $\mathrm{HCl} \mathrm{pH} 8.0$ (19).

Translation inhibitor $\left(680 \mu \mathrm{g} \cdot \mathrm{ml}^{-1}\right.$, in 0.2 M-sodium borate $\mathrm{pH} \mathrm{9.0)} \mathrm{was} \mathrm{carbamylated}$ with $0.2 \mathrm{M}$-potassium cyanate at $30^{\circ} \mathrm{C}$ for $24 \mathrm{~h}$
(22). Aliquots were removed at appropriate time intervals and dialyzed against $5 \mathrm{~mm}$-ammonium bicarbonate to stop the reaction.

Carboxyl groups in translation inhibitor $(570$ $\mu \mathrm{g} \cdot \mathrm{ml}^{-1}$, in $0.1 \mathrm{M}-\mathrm{NaCl}$ adjusted to $\mathrm{pH} 4.75$ with $\mathrm{HCl}$ ) were modified at room temperature by $0.1 \mathrm{M}$-EDC employing $1 \mathrm{M}$-glycine ethyl ester as nucleophile (7). During $90 \mathrm{~min}$ aliquots were removed at appropriate time intervals and the reaction was stopped by addition of 2.5 volumes of $2 \mathrm{M}$-sodium acetate $\mathrm{pH} 4.75$. To regenerate modified tyrosines (6) the reaction mixture was adjusted to $\mathrm{pH} 7.0$ and incubated with $0.5 \mathrm{M}$-hydroxylamine at room temperature for $5 \mathrm{~h}$. Excess of reagents was removed by dialysis against water.

To modify arginines, translation inhibitor $\left(610 \mu \mathrm{g} \cdot \mathrm{ml}^{-1}\right.$, in $0.2 \mathrm{M}$-sodium borate $\left.\mathrm{pH} 9.0\right)$ was incubated with $50 \mathrm{~mm}-\mathrm{CHD}$ at $37^{\circ} \mathrm{C}$ for 2 $\mathrm{h}$ with stirring (18). Aliquots were removed at appropriate time intervals and dialyzed against 20 mm-sodium borate pH 9.0.

Histidines in the translation inhibitor ( 850 $\mu \mathrm{g} \cdot \mathrm{ml}^{-1}$, in $50 \mathrm{~mm}$-sodium phosphate $\mathrm{pH} 6.0$ ) were modified by three portions of $\operatorname{DEP}(2.5 \%$ in 95\% ice-cold ethanol, $15 \mu \mathrm{l} \cdot \mathrm{ml}^{-1}$ ) added over a period of $30 \mathrm{~min}$ at room temperature (15). The reaction was stopped by dialysis against water.

Tryptophans were alkylated with DMNBS-Br or oxidized with NBS. Three portions of solid DMNBS-Br $\left(50 \mathrm{mg} \cdot \mathrm{ml}^{-1}\right)$ were added to the translation inhibitor $\left(500 \mu \mathrm{g} \cdot \mathrm{ml}^{-1}\right.$, in $50 \mathrm{~mm}$ sodium acetate $\mathrm{pH} 3.5$ ) over a period of $30 \mathrm{~min}$ (13). Then the reaction mixture was left at room temperature for an additional $90 \mathrm{~min}$ and finally dialyzed against water. Oxidation was performed by adding portions of $10 \mathrm{~mm}-\mathrm{NBS}$ in 50 mM-sodium acetate $\mathrm{pH} 4.3$ at $25{ }^{\circ} \mathrm{C}$ to the translation inhibitor $\left(450 \mu \mathrm{g} \cdot \mathrm{ml}^{-1}\right.$ in the same buffer) to a final concentration of $0.29 \mathrm{~mm}$-NBS at which no further decrease in the absorbance at $280 \mathrm{~nm}$ was observed (8). The number of modified tryptophan residues was calculated as described from the loss of absorbance at $280 \mathrm{~nm}$ and excess reagent was then quenched by addition of 15 mu-tryptophan (24). The effects of NBS on other amino acid residues were examined by amino acid analysis.

For oxidation of methionines, the translation inhibitor $\left(450 \mu \mathrm{l} \cdot \mathrm{ml}^{-1}\right.$, in $1 \mathrm{mM}-\mathrm{HCl}$ containing 
0.5 mm-EDTA pH 3.0) was incubated with $1 \%$ hydrogen peroxide at $30^{\circ} \mathrm{C}$ for $1 \mathrm{~h}$. The reaction was stopped by dialysis against $5 \mathrm{~mm}-\mathrm{HCl}$ followed by water.

\subsection{Preparation and purification of peptide fragments}

Nitrated translation inhibitor $(1.9 \mathrm{mg})$ (see section 2.2) was reduced with 2-mercaptoethanol, cleaved with cyanogen bromide and the resulting fragments were separated as described previously (3). Endoproteinase Lys-C digestions were performed and subfragments were separated by RP-HPLC as reported elsewhere (3). Unmodified translation inhibitor was subjected to the same fragmentations as a control.

\subsection{Analytical procedures}

Inhibition of the cell-free protein synthesis was assayed in the rabbit reticulocyte lysate system as previously described (1). Amino acid compositions of protein samples, hydrolyzed in
$6 \mathrm{M}-\mathrm{HCl}$ at $110^{\circ} \mathrm{C}$ for $24 \mathrm{~h}$, were analyzed on a Durnum D-500 amino acid analyzer (1). Contents of homocitrulline were determined by extrapolation to zero-time after hydrolysis for 24 and $48 \mathrm{~h}$. Tryptophan was determined by amino acid analysis after hydrolysis in $4 \mathrm{M}$ methanesulfonic acid at $125^{\circ} \mathrm{C}$ for $20 \mathrm{~h} \mathrm{(16) \text {. }}$ 3-Nitrotyrosine contents were measured spectrophotometrically at 428 and $381 \mathrm{~nm} \mathrm{(23).}$ Extent of histidine modification was measured spectrophotometrically at $242 \mathrm{~nm}$ as described (20). Primary amino groups were determined by trinitrobenzene sulfonic acid (11). Extent of modification of arginine and methionine was deduced from the loss of these amino acids and the number of modified carboxyl groups was estimated from incorporated glycine, as determined by amino acid analysis.

\section{RESULTS}

\subsection{Chemical modification of translation inhibitor}

The effects and extents of various chemical modifications of the translation inhibitor are

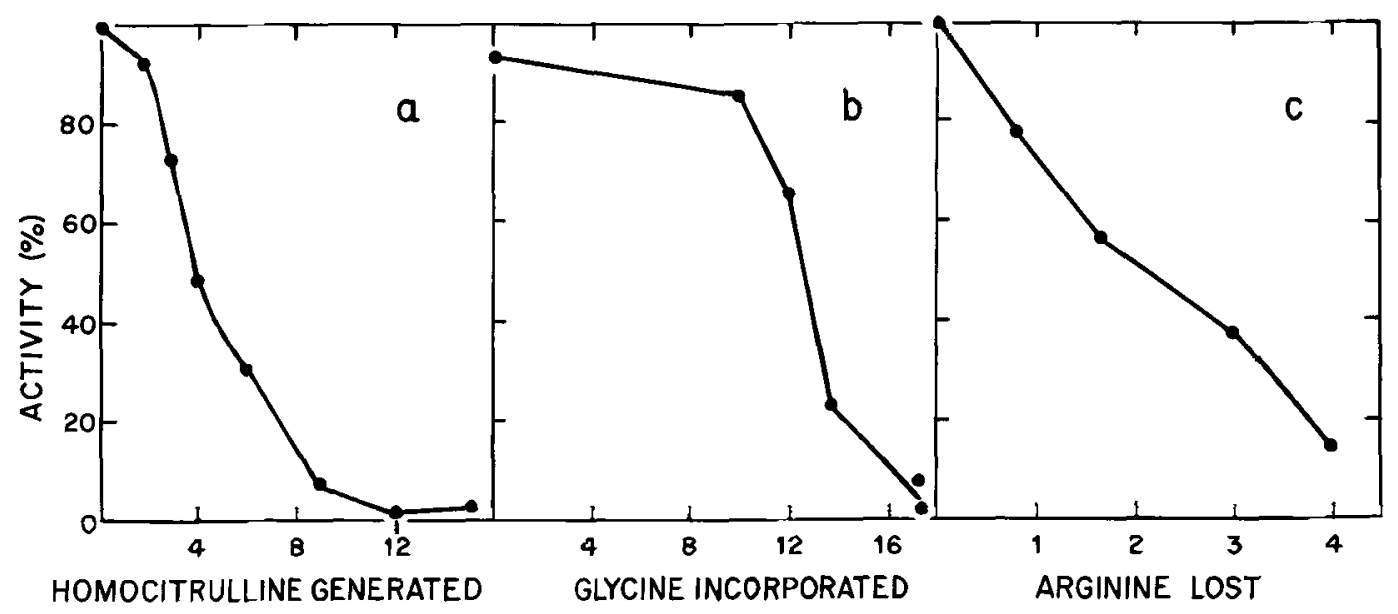

\section{RESIDUES PER MOLECULE}

Figure 1. Effect on the activity of translation inhibitor by modification of a. lysyl residues with potassium cyanate over a period of $24 \mathrm{~h}$, b. carboxyl groups with EDC and glycine ethyl ester over $90 \mathrm{~min}$, and c. arginyl residues with CHD over $2 \mathrm{~h}$. Samples were removed from the respective reaction mixtures at appropriate time intervals, dialyzed and the extent of modification and remaining activity (employing 8 fold the $\mathrm{ID}_{50}$-value of the unmodified inhibitor) were measured as described in section 2.4 . 
Table I. Chemical modification of the barley translation inhibitor II

\begin{tabular}{llccc}
\hline Reagent & $\begin{array}{l}\text { Residue } \\
\text { modified }\end{array}$ & $\begin{array}{l}\text { Total number } \\
\text { of residues }\end{array}$ & $\begin{array}{l}\text { Number of modified } \\
\text { residues }\end{array}$ & $\begin{array}{l}\text { Activity } \\
(\%)\end{array}$ \\
\hline TNM & Tyr & 4 & 1.0 & 25 \\
KCNO & Lys & 22 & 13 & $1:$ \\
EDC & -COOH & $25^{\text {b) }}$ & 19 & 53 \\
CHD & Arg & 10 & 4.3 & 77 \\
DEP & His & 6 & 5.6 & 0 \\
& Lys & 22 & 9.1 & 87 \\
DMNBS-Br & Trp & 4 & 2.0 & 1 \\
NBS & Trp & 4 & 2.3 & \\
& Tyr & 4 & 2.1 & 87 \\
\hline
\end{tabular}

a) In percent of the inhibition obtained at the same concentration of unmodified control, i.e. 20 fold the $\mathrm{ID}_{50}$-value found for the unmodified inhibitor (1).

b) From the sequence (3).

The chemical modification conditions are described in section 2.2 and activity and extent of modification were determined for derivatives at the end of the modification experiment.

summarized in Table I and Figures la-c. The activity of modified and unmodified translation inhibitor was compared at 8 or 20 fold the ID $_{50}$-value of the unmodified inhibitor (1).

Nitration with TNM of one of the four tyrosyl residues present in barley protein synthesis inhibitor caused a substantial decrease in the activity (Table I).

About 13 \&-amino groups were carbamylated with potassium cyanate (Table I), the $\alpha$-amino group of the native protein is acetylated (3). The activity of the translation inhibitor gradually decreased with increasing extent of carbamylation and no appreciable activity was detected when nine or more lysyl residues were modified (Figure 1a).

EDC-treatment of the translation inhibitor in the presence of glycine ethyl ester resulted in incorporation of 19 glycyl residues compared to the 25 free carboxyl groups present in the molecule (3). Initial modification of 10 carboxyl groups had little effect on the activity; the important loss of activity resulted from further modification (Figure 1b; Table I).

The activity of the translation inhibitor decreased, with increasing extent of arginine modification, to $10 \%$ of the initial value when assayed at 8 fold the $\mathrm{ID}_{50}$-value (Figure 1c). How- ever, at a higher concentration of the modified protein ( 20 fold the $\mathrm{ID}_{50}$-value) a considerable activity was observed (Table I).

Essentially, all histidines were modified with DEP. At the same time, however, about 9 lysyl residues were modified as judged from the decrease in the amount of free amino groups. At 20 fold the $\mathrm{ID}_{50}$-value this derivative of translation inhibitor showed no activity (Table I), but since lysyl residues are required for the activity (see above) no evidence is obtained for a specific role of histidyl residues.

Two tryptophanyl residues of the translation inhibitor were alkylated with DMNBS-Br without appreciable loss of activity. However, treatment with NBS resulted in loss of two tryptophans, two tyrosines and three histidines and complete inactivation of the inhibitor (Table I); an effect that is most likely due to modification of tyrosyl residues. Oxidation of about two methionyl residues by hydrogen peroxide did not greatly influence the activity (Table I).

\subsection{Identification of an essential tyrosyl residue \\ In order to identify the essential tyrosyl residue in the primary structure the large}




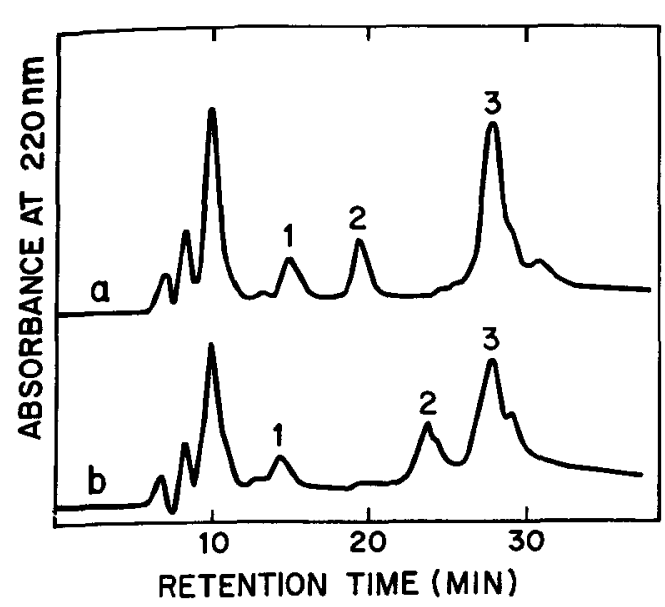

Figure 2. HPLC-elution profiles of peptide fragments obtained by digestion of the cyanogen bromide fragment Ala(5)-Hse(171) (CB2, ref. 3) from unmodified (a) and nitrated (b) translation inhibitor with endoproteinase Lys-C. After desalting, the mixtures were separated by HPLC on a wide pore $\mathrm{C}_{18}$ column with elution by a linear gradient from 21 to $40 \%$ 1-propanol in $0.1 \%$ trifluoroacetic acid over $40 \mathrm{~min}$ at a flow rate of $0.5 \mathrm{ml} \cdot \mathrm{min}^{-1}$. The absorbance at $220 \mathrm{~nm}$ was monitored. Peaks 1, 2, and 3 correspond to the fragments, Asn(7)-Lys(36), Ala(69)-Lys(91) and Ser(92)Lys(126), respectively.

cyanogen bromide fragment, $\mathrm{CB} 2=\mathrm{Ala}(5)-$ Hse(171) (3) which contains all four tyrosines of the translation inhibitor, was prepared from nitrated translation inhibitor with 1.3 nitrotyrosine residues per molecule. The residues $\operatorname{Tyr}(26), \operatorname{Tyr}(86), \operatorname{Tyr}(110)$ and $\operatorname{Tyr}(117)$ are located in three peptide fragments, Asn(7)Lys(36), Ala(69)-Lys(91) and Ser(92)-Lys(126), obtained by digestion of CB2 with endoproteinase Lys-C (3). These fragments from both nitrated and unmodified inhibitor were purified by RP-HPLC and identified by amino acid analysis (data not shown). A clear increase in the retention time was observed for $\mathrm{Ala}(69)$ Lys(91) upon nitration (compare Figure 2a and b) which suggests an increase of the hydrophobicity of this fragment due to modification of Tyr(86). No significant change in elution position was observed for the other fragments. Spectrophotometric analysis of the three fragments verified that only Tyr(86) was nitrated (Table II).
Table II. Number of tyrosyl and 3-nitrotyrosyl residues in peptide fragments generated by endoproteinase Lys-C

\begin{tabular}{lccc}
\hline \multirow{2}{*}{ Peptide } & Unmodified & \multicolumn{2}{c}{ Modified } \\
\cline { 2 - 4 } & Tyr & Tyr & 3-nitro-Tyr ${ }^{\text {a) }}$ \\
\hline Asn(7)-Lys(36) & 1.0 & 1.0 & $\leqslant 0.1$ \\
Ala(69)-Lys(91) & 1.0 & 0.2 & 0.9 \\
Ser(92)-Lys(126) & 2.0 & 1.9 & $\leqslant 0.1$ \\
\hline
\end{tabular}

a) Determined spectrophotometrically (19).

\section{DISCUSSION}

The translation inhibitor II from barley seeds strongly inhibits animal cell-free protein synthesis (1). The activity of this inhibitor was sensitive to chemical modification of carboxyl groups and of tyrosyl, lysyl, and arginyl residues. Noteworthy, the specific nitration of $\operatorname{Tyr}(86)$, one of four tyrosyl residues in the molecule, caused a substantial loss of the activity, suggesting that this residue plays a role in the function of the inhibitor. $\operatorname{Tyr}(86)$ is conserved in the sequence of the ricin A-chain (3) and tyrosyl residues have previously been suggested to be important for the activity of translation inhibitors such as PAP (14) and ricin A-chain (27), but the essential residues were in these cases not identified in the sequence.

Lysines and arginines are also demonstrated to be important for the activity of the barley translation inhibitor, whereas the role of histidines remains uncertain. The type of process which catalytically inactivates the function of ribosomes has only been identified for $\alpha$-sarcin, a basic microbial translation inhibitor of approx. $M_{r} 16.000$, which hydrolyses a specific nucleotide linkage in the large ribosomal RNA $(9,21)$. Attempts to demonstrate a similar action of the barley inhibitor failed (1). Although the barley inhibitor appears to have a function different from PAP and ricin A-chain $(2,17)$, these three inhibitors seem all to possess essential lysyl and/or arginyl residues $(14,28$; this work). Modification of lysyl groups had a larger effect on the barley inhibitor as compared with PAP (14), while PAP (14) and ricin A-chain (28) seemed more sensitive to modification of arginines. A simple explanation for this difference 
might be that both ricin A-chain and PAP contain only few lysines and many arginines, whereas the opposite is true for the barley inhibitor $(1,3)$. In gelonin arginines were also essential, while extensive modification of lysines, tyrosines, tryptophans, or histidines had no effect on the activity (26). It may be speculated that basic residues participate in interactions between these inhibitors and ribonucleic acids or nucleotides.

\section{ACKNOWLEDGEMENTS}

We are indepted to Dr. Flemming M. PoulSEN and Prof. MARTIN OTTESEN for discussions and critical revision of the manuscript. Dr. Anders BRANDT, Department of Physiology, Carlsberg Laboratory is thanked for advice and help with the cell-free protein synthesis assay. Ms. BODIL CORNELIUSSEN is acknowledged for excellent technical assistance with amino acid analyses. KATSUHIKO ASANO is on leave from Kirin Brewery Co., Ltd., Tokyo, Japan and acknowledges their financial support.

\section{REFERENCES}

1. ASANo. K. B. Svensson \& F. M. Poulsen: Isolation and characterization of inhibitors of animal cellfree protein synthesis from barley seeds. Carlsberg Res. Commun. 49, 619-626 (1984)

2. Asano, K.. B. Svensson, F. M. Poulsen, O. NyGARD \& L. NILSSON: Effects of translation inhibitor from barley seeds on the steps of animal cell-free protein synthesis. Carlsberg Res. Commun. 51, 75-81 (1986)

3. Asano. K. B. Svensson, I. Svendsen, F. M. POULSEN.\& P. ROEPSTORFF: The complete primary structure of protein synthesis inhibitor II from barley seeds. Carlsberg Res. Commun. 51, 129-141 (1986)

4. BARBIERI, L \& F. STIRPE: Ribosome-inactivating proteins from plants: properties and possible uses. Cancer Surveys 1, 489-520 (1982)

5. BRANDT. A. \& J. INGVERSEN: Isolation and translation of hordein messenger RNA from wild type and mutant endosperm in barley. Carlsberg Res. Commun. 43, 451-469 (1978)

6. Carraway, K. L. \& D.E. Koshland.JR.: Reaction of tyrosine residues in proteins with carbodiimide reagents. Biochim. Biophys. Acta 160, 272-274 (1968)
7. Carraway. K. L. \& D. E. Koshland, JR: Carbodiimide modification of proteins. Meth. Enzymol. $25,616-623(1972)$

8. Clakke, A. J. \& B. Svensson: The role of tryptophanyl residues in the function of Aspergillus niger glucoamylase G1 and G2. Carlsberg Res. Commun. 49, 111-122 (1984)

9. ENDO Y.\& I.G. WOOL: The site of action of $\alpha$-sarcin on eukaryotic ribosomes. The sequence of the $\alpha$-sarcin cleavage site in $28 \mathrm{~S}$ ribosomal ribonucleic acid. J. Biol. Chem. 257, 9054-9060 (1982)

10. GeSSNER. S. L. \& J. D. IRVIN: Inhibition of elongation factor 2-dependent translocation by the pokeweed antiviral protein and ricin. J. Biol. Chem. 255, 3251-3253 (1980)

11. HABEEB. A. F. S. A.: Determination of free amino groups in proteins by trinitrobenzene sulfonic acid. Anal. Biochem. 14, 328-336 (1966)

12. HoPp. H. E.. S. K. RaSMUSSEN \& A. BRANDT: Organization and transcription of $B 1$ hordein genes in high lysine mutants of barley. Carlsberg Res. Commun. 48. 201-216 (1983)

13. HORTON. H. R. \& W. P. TUCKER: Dimethyl(2-hydroxy-5-nitrobenzyl)sulfonium salts. Water-soluble environmentally sensitive protein reagents. J. Biol. Chem. 245. 3397-3401 (1970)

14. IRvin. J. D. \& G. M ARon: Chemical modifications of pokeweed antiviral protein: Effects upon ribosome inactivation, antiviral activity and cytotoxicity. FEBS Letter 148,127-130 (1982)

15. LiTTLE. C.: The histidine residues of phospholipase C from Bacillus cereus. Biochem. J. 167,399-404 (1977)

16. LiU. T. Y.\& Y. H. CHANG: Hydrolysis of proteins with p-toluenesulfonic acid. Determination of tryptophan. J. Biol. Chem. 246, 2842-2848 (1971)

17. NilsSon.L. K. Asano. B. SVEnsson, F. M. Poulsen \& O. NYGÄRD: Reduced turnover of the elongation factor EF-1'ribosome complex after treatment with the protein synthesis inhibitor II from barley seeds. Biochim. Biophys. Acta 868, 62-70 (1986)

18. Patthy. L \& E. L. SMith: Identification of functional arginine residues in ribonuclease $A$ and lysozyme. J. Biol. Chem. 250, 565-569 (1975)

19. Riordan. J. F. \& B. L. Vallee: Nitration with tetranitromethane. Meth. Enzymol. 25, 515-521 (1972)

20. ROOSEMONT.J. L.: Reaction of histidine residues in proteins with diethylpyrocarbonate: Differential molar absorptivities and reactivities. Anal. Biochem. 88, 314-320 (1978)

21. SCHINDLER, D. G.\&J. E. DAVIES: Specific cleavage of ribosomal RNA caused by alpha sarcin. Nucleic Acid Res. 4, 1097-1110 (1977)

22. STaRK. G. R: Modification of proteins with 
cyanate. Meth. Enzymol. 11, 590-594 (1967)

23. Sokolovsky, M., J. F. Riordan \& B. L. ValleE: Tetranitromethane. A reagent for the nitration of tyrosyl residues in proteins. Biochemistry 5,3582 3589 (1966)

24. SPANDE, T. F. \& B. WitKoP: Determination of the tryptophan content of proteins with N-bromosuccinimide. Meth. Enzymol. 11, 498-506 (1967)

25. SPERTI. S. \& L. MONTANARO: Ricin and modeccin do not inhibit the elongation factor 1-dependent binding of aminoacyl-tRNA to ribosomes. Biochem. J. 178, 233-236 (1979)
26. Srinivasan, Y., M. P. Ramprasad \& A. Surolia: Chemical modification studies of gelonin. Involvement of arginine residues in biological activity. FEBS Lett. 192, 113-118 (1985)

27. Taira, E., N. Yoshizuka, G. Funatsu \& M. FuNATSU: Effects of physical and chemical treatments on the biological activity of ricin D. Agric. Biol. Chem. 42, 1927-1932 (1978)

28. Watanabe, $\mathrm{K}$ \& G. Funatsu: Involvement of arginine residues in inhibition of protein synthesis by ricin A-chain. FEBS Lett. 204, 219-222 (1986)

Accepted by S.O. ANDERSEN 